Gesnerus 70/1 (2013) 127-150

\title{
Laughter in popular games and in sport. The other health of human play
}

Henning Eichberg

\section{Summary}

Hurling in Cornwall, la soule in Britanny, Shrovetide football in England: Popular games have normally been treated as forerunners of modern sport, sport having regulated the space and the time of the game, the (non-) violence of behaviour, the control of results, the planning, strategy, tactics, techniques and evaluation of the competitive action. This is told as a story of social improvement and progress - and about turning unhealthy wildness into civilized 'healthy' sport activity. What sociological analysis of game-playing tended to ignore was the laughter of the participants. With the seriousness of modern sport, as it was established in the nineteenth century, a culture of laughter disappeared. This study tries to counter this mainstream by a phenomenology of laughter in popular games. A contrasting attention is turned towards the seriousness of sporting competition, the smile in modern sport and fitness, and the 'underground' dimension of laughter in modern sports. By comparative analysis, laughter reveals as a bodily discourse about the imperfect human being. It tells an oppositional story about the perfectionism in the order of Western thinking - in sports as well as in health. The bodily 'physiology' of laughter, the exploding psychical energy, and the inter-bodily social relations in laughter and play and game point towards the multidimensionality of health, as it was formulated by WHO: as "physical, mental, and social well-being".

Keywords: Laughter and health, modern sport, popular games

Henning Eichberg, Institute of Sports Science and Clinical Biomechanics, Faculty of Health Sciences, University of Southern Denmark, Odense (DK), (heichberg@health.sdu.dk). 


\section{Résumé}

Le hurling en Cornouailles, la soule en Bretagne, le foot shrovetide en Angleterre: les jeux populaires ont généralement été traités comme les précurseurs du sport moderne, le sport ayant régulé l'espace et le temps du jeu, la (non-)violence du comportement, le contrôle des résultats, l'organisation, la stratégie, les tactiques, les techniques et l'évaluation de l'action compétitive. Ceci est généralement présenté comme une histoire du progrès social - ou encore d'une sauvagerie dégénérée transformée en activité sportive saine et civilisée. Ce que l'analyse sociologique de l'action ludique a eu tendance à ignorer est le rire des participants. Avec le sérieux du sport moderne, instauré au XIX ${ }^{\mathrm{e}}$ siècle, une culture de rire a disparu. Cette étude essaie de contrecarrer ce courant dominant par la phénoménologie du rire dans les jeux populaires. Une approche contrastée se penche sur le sérieux de la compétition du sport, le sourire dans le sport moderne et le fitness, et la dimension souterraine du rire dans les sports modernes. Par l'analyse comparative, le rire se révèle comme un discours corporel sur l'imperfection de l'être humain. Il propose un récit d'opposition face au perfectionnisme dans la pensée occidentale - en sport comme en santé. La «physiologie» corporelle du rire, l'explosion de l'énergie psychique, et les relations sociales intercorporelles dans le rire et le jeu pointent vers la multi dimensionnalité de la santé, telle qu'elle fut formulée par l'OMS: un «bien-être physique, mental et social».

\section{Two cases of folk games - healthy? unhealthy?}

Hurling in Cornwall around $1600 .{ }^{1}$ Two villages fight their way through the landscape, unfolding a picture of game, violence, and laughter. People meet on a holiday, following an older tradition. Two gentlemen from the local nobility have donated the silver ball, which the fight will now be about. As soon as the ball is given up, the two teams, which nobody has measured in number or strength, try to grasp it in order to bring it to their respective goals. The goal may be their village pub or the seat of the patron or some other agreed upon place in the settlement. All through the landscape, over hills and through waters, across fields and hedges, the wild chase proceeds. If one of the fighters hangs fast in the thorny bush, or if twenty or thirty fight in the

1 Earlier versions of this article were published in Finnish (Eichberg 2008b), English, French and Spanish (Eichberg 2010a, b, c, d). 
muddy water for the ball, the merriment is all the greater. Finally, the ball will reach one of the goals and there the crowd will meet. And all together they drink the beer, which is lavishly provided by the patron of the victorious team. ${ }^{2}$

Another case is from rural Denmark in the nineteenth century. An elderly farmer remembered in 1913 a traditional ball game from his youth: In the village of Ljørslev it was custom that the young people on second or third Easter day early in the morning went to the churchyard to play ball. The participants formed two teams, and each of them had their goal at one end of the churchyard. The ball had to be given up three times, and the third time they should leave the goal, and then they could be hit by the ball. The game was similar to longball. ${ }^{3}$ If the ball was thrown over the wall of the churchyard, there should be paid a penalty, which was enjoyed in the afternoon. ${ }^{4}$

Historiographers and sociologists have normally treated games like these as forerunners of modern sport. Where popular games were not yet standardized regarding space, time, size of teams and rules, sport has regulated all these dimensions of the game, the (non-)violence of behaviour, the control of results, the planning, strategy, tactics, techniques and evaluation of the competitive action. This is typically told as a story of social-functional improvement - as a story of progress.

What analysis tends to ignore is the laughter of the participants. The games of popular culture cannot be understood if one does not listen to the noise of enjoyment and pleasure, the ironical calls, the obscene remarks, the laughter about the situational comic of failing and tumbling. All this intonation is not just a side-effect of the game, it is central to the social-bodily process. In this respect, the games were not only forerunners, but they represented another type of social interaction. They were at the bodily core of popular festivity, thus being another type of social practice than modern sport. And laughter is an indicator of these fundamental differences.

These differences can be seen in surprising new perspective in regard to the very recent hygienic turn of sport. Through at least one century, sport had been practiced as a way of competitive work on line with industrious life, but during the recent one or two decades it has obtained a new aspect, as a practice of healthy lifestyle. Whether this is just some sport-political rhetoric

2 Carew 1811, 195-199. - A survival from this type of games is the Ashbourne Shrovetide Football, called "one of the world's oldest, largest, longest and maddest football games". It is documented as early as 1349 and is famous for its violent dynamics all through landscape and water. On this and further surviving ballgames in Britain see: Hornby 2008.

3 Longball is a cricket-like game of batting the ball, running and hitting. It is played by children in Denmark up to the present day.

4 Korsgaard 1986, 13. 
or really begins to dominate the practice of sports, may remain an open question, at the time being. Anyway, the new orientation opens for a new attention to what is healthy or unhealthy in sport - and in games. Popular games were repressed through centuries with arguments against their disorder, violence - and their unhealthy character. After the recent hygienic turn of sports, however, this argument may turn around - to what end? Anyway, during industrial modernity the culture of popular laughter disappeared in the seriousness of modern sport ${ }^{5}$. Let us look closer at this historical transformation - and forget health for a while, in order to return to the health questions with fresh eyes.

\section{Phenomenology of laughter in popular games}

The games and competitions in pre-modern society were rich of laughterprovoking actions, and some of these practices are still known to us today. But laughter is not a simple single thing - there are many different forms of laughter produced by different bodily practices and exploding in different situations of social interaction. On the other hand, laughter cannot be understood as just a variety of strange phenomena, detailed differences and particularities in certain cultures, which are under selective and isolated observation ${ }^{6}$. The anthropology of laughter demands attention to patterns and change of patterns, which tell about societal contradictions and change at large. This requires a differential phenomenology of laughter in bodycultural practice. We may talk about the laughter at hitting the point, the laughter when playing the loser, the laughter of hindering and tumbling, the laughter of mock fight, the laughter at the grotesque body, the laughter at the fool, and the laughter of carnival.

\section{Hitting the target - the surprising point of movement}

In a typical and very elementary way, laughter is provoked by the game of hitting 'the point'. Modern throwing sports are typically designed in a way, that the outcome is measured in centimetres - corresponding to the slogan citius, altius, fortius! - but this pattern does not play any important role in traditional popular games. There, the decisive point is hitting a certain target.

5 Carter, Krüger 1990.

6 Nitschke, Stagl, Bauer 2009. 
This particular action is the origin of popular games like bowling, quoits (casting a horseshoe) and curling. And one can literally 'hear' these games they have the intonation of laughter.

If an athlete throws the ball or the discus, there is nothing to laugh at the distance, which has been obtained. But the situation of hitting the target, or failing the target, or a new, unexpected configuration of the balls created by a new cast give different occasions of surprise and laughter. This pattern of 'hitting the point' corresponds to the fact, that the joke has a certain 'point', too. Laughter is pointed by a bodily and psychic explosion - the burst of laughter (éclat de rire - in Gelächter ausbrechen). As with throwing, similar patterns can be found in running. Racing forward as quickly as possible citius! - does not as such make up the fascination of a popular game. The point is to touch or to catch someone. ${ }^{7}$ In rural Brittany, running was and is still nowadays practiced as a competition of catching a chicken. The same again is true for swimming. Swimming has been popular through many centuries, but was never practiced along parallel courses for a result of time. In a game from Portugal, boys swim out into the water trying to catch a duck. The unpredictable target makes this a popular game.

\section{Playing the loser}

Some of the activities of catching may appear as a 'game of the loser', because people do not strive to be 'the first', but try to avoid being 'the last'. They do not want to be the 'scapegoat' or the 'blind-man's-buff'. But is this avoidance really the point of those many games of run-and-catch in the world of popular culture? Let us look closer at the children's play "You can't catch me!"The object of the game is to tag or touch other players - and to run away from each other in order to avoid being caught oneself. Usually one player 'is it' and has to chase and tag the other players, one of whom then becomes the new person who 'is it' ${ }^{\prime}$. From a modern sportive perspective, this looks like a game of running quickly and determining the slowest runner. In some respects it looks sportive, though it does not culminate with a winner, but rather with a loser. It is 'not yet sport' - in the eyes of a sportive observer. If the game really were to be practiced in a sports-like way, however, the game would not function. The slowest runner would very soon stay behind in tears, and the game would end abruptly. If the game shall continue, the players must

7 The ancient game of Kabbadi from Punjab shows how this type of movement could be transformed into a modern competitive team sport expanding into other Asian countries. 8 Møller 1997; Møller 1984. 
act against the rule of speed, winning, and excellence in achievement. Instead, the quicker runner will approach the slower one, teasing and mocking: 'You can't catch me, tra-la-la!' The quick runner provokes others in order to be touched him- or herself because only this brings flow into the game. It is in the interest of all players that no real loser is produced. Catch and run is not about avoiding to being a loser - it is a way of playing the loser.

Characteristic for this type of action is a certain 'intonation' of the game it is laughter. Losing can be funny; it has features of the grotesque. If the quicker runner is touched by the slower one - whether voluntarily in order to make the game go on, or involuntarily because of some fortuitous situation - this will create a ridiculous atmosphere of joking, mocking and teasing. Playing the loser makes the players laugh. The play of chase and tag can be heard on distance, and it is another sound than the running on the athletic track. Instead of winning and instead of avoiding the position of the scapegoat, the deeper appeal of the game is something else: Don't take it seriously!

\section{Hindering and tumbling - moving in curved lines}

Typical for popular games are also the situations of hindering and tumbling. Tumbling is typical of the movement of clowns - provoking laughter. Competitive races have since long time been part of popular culture - but they implied the practice of hindering each other. This was excluded by modern sportization, when running was reorganised to be contested on parallel tracks - without touching each other - and aiming at the production of a certain objective, quantified result. From the popular culture of festivity and game, some few running events have been preserved, nowadays transformed into folkloristic events. Well-known is the Markgröninger Schäferlauf, which has its origin in a race of shepherds in Württemberg. It is continued as an annual folkloristic and tourist event. The race is known for its especially attractive feature that the 'shepherdesses' are allowed to hinder each other on the track. ${ }^{9}$

All this is, however, not only a question of history versus modernity. The practical problem arises with every new generation entering the educational system. When children are sent on the track to learn the 'correct' sportive way of behaviour, they will begin by trying to hinder each other and joke about by pushing others. Step by step, they have to be disciplined: Don't push each other, don't shove! Typical of the popular type of race is also the sack-

9 Tomschik 1971; Depping 1881, 137-141, 250-253, 275. 
race. The sack is an artificial handicap to make the participants tumble, and again you can 'hear' the event - by its laughter. In popular race, tumbling is not a mistake or a drama, as it is deplored in modern athletics and described in tragic terms, but it is a central, carnivalistic feature of movement. In the same category are games of balance. Balancing is a play with imbalance and includes the probability to fall. The merriment of falling is a typical pattern in popular games - in contrast to sport, where the fall - for instance falling down from the high bar of gymnastics - is a serious mistake.

The laughter accompanying popular types of movement - racing, balancing, jumping - may be connected with the contradiction between the curved line and the straight line. Sidestepping, outcrop curvature (German: Hakenschlagen) and detour make up an important source of amusement and surprise. In this respect, tumbling can be related to the labyrinthine movement, which contrasts the straight line of modern sports race. ${ }^{10}$

\section{Mock fighting}

One can also see a relation between the curved movement of popular racing, tumbling, and certain forms of fight. This is visible in rowing tournaments of folk culture. Instead of competing on parallel courses for records like in sports rowing, the people of folk boating battled from boat to boat and tried to push each other into the water ${ }^{11}$ The water tournament, thus, was a mock fight and ironic quarrel - this is what in Danish language is called dyst. In contrast to the serious fight of warriors and to the seriously regulated competition of modern sport, dyst-fight includes a potential of mocking and laughter. A popular game playing particularly on these qualities of movement is the Nordic game "Markus and Lukas". Two fighters stand at two sides of a table, both blindfolded, and with a soft "sword" in the hand, consisting of a piece of cloth or a rolled newspaper. They shift calling each other by their names "Markus" and "Lukas" and then hit towards the other in the direction of the voice. The game is a variation of blind man's buff - for two persons. The participants as well as the spectators laugh. ${ }^{12}$ The rich world of pulling from German Fingerhakeln to tug-of-war - has strong elements of this mock fight, too. Tug-of-war was one of the few Olympic disciplines, which were excluded. Serious athletes regarded it as "something of a joke". ${ }^{13}$

10 Eichberg 2005.

11 Henningsen 1949.

12 Møller 1997, 100-101.

13 Eichberg 2003.

Gesnerus 70 (2013) 


\section{The grotesque body}

The game mouth pull, which is popular among Northern Inuit people, shows a further dimension of the culture of laughter, the display of the grotesque body. In mouth pull, two persons stand shoulder by shoulder. They put their arms around the partner's neck, symmetrically. Opening their lips, they grab with their forefinger into the other's mouth. On a signal, they start pulling. The mouths and cheeks are distorted, the eyes roll, they develop grotesque features in their opponents. Intensifying their efforts, the competitors turn their heads outward, trying both to relieve the pain and resist effectively at the same time, until one of them gives up. ${ }^{14}$ Moreover, this competition can be 'heard'. Spectators react on the eccentric deformation of the face. The game exhibits the grotesque body.
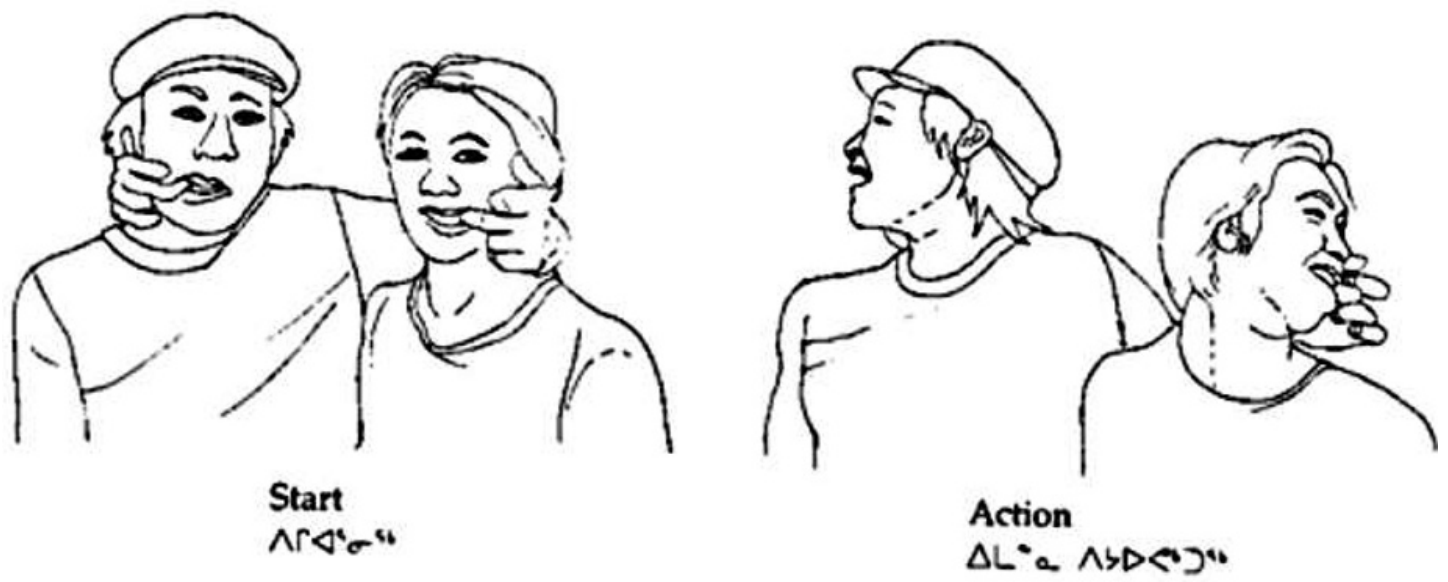

Inuit mouth pull. From: Keewatin Inuit Associations, 1989: Inuit games. Department of Education, Regional Resource Center, Government of the North West Territories, Rankin Inlet, Canada, p. 38.

A still more eccentric event of pulling was portrayed by the Greenlandic painter Aron of Kangeq in the mid-nineteenth century. His painting showed the "arse" pull: A group of Inuit assemble around two men competing with their trousers down. People used a short rope with two pieces of wood fastened at the ends. They put these pieces through their legs and behind their buttocks in order to tug the rope by their back muscles. ${ }^{15}$ 


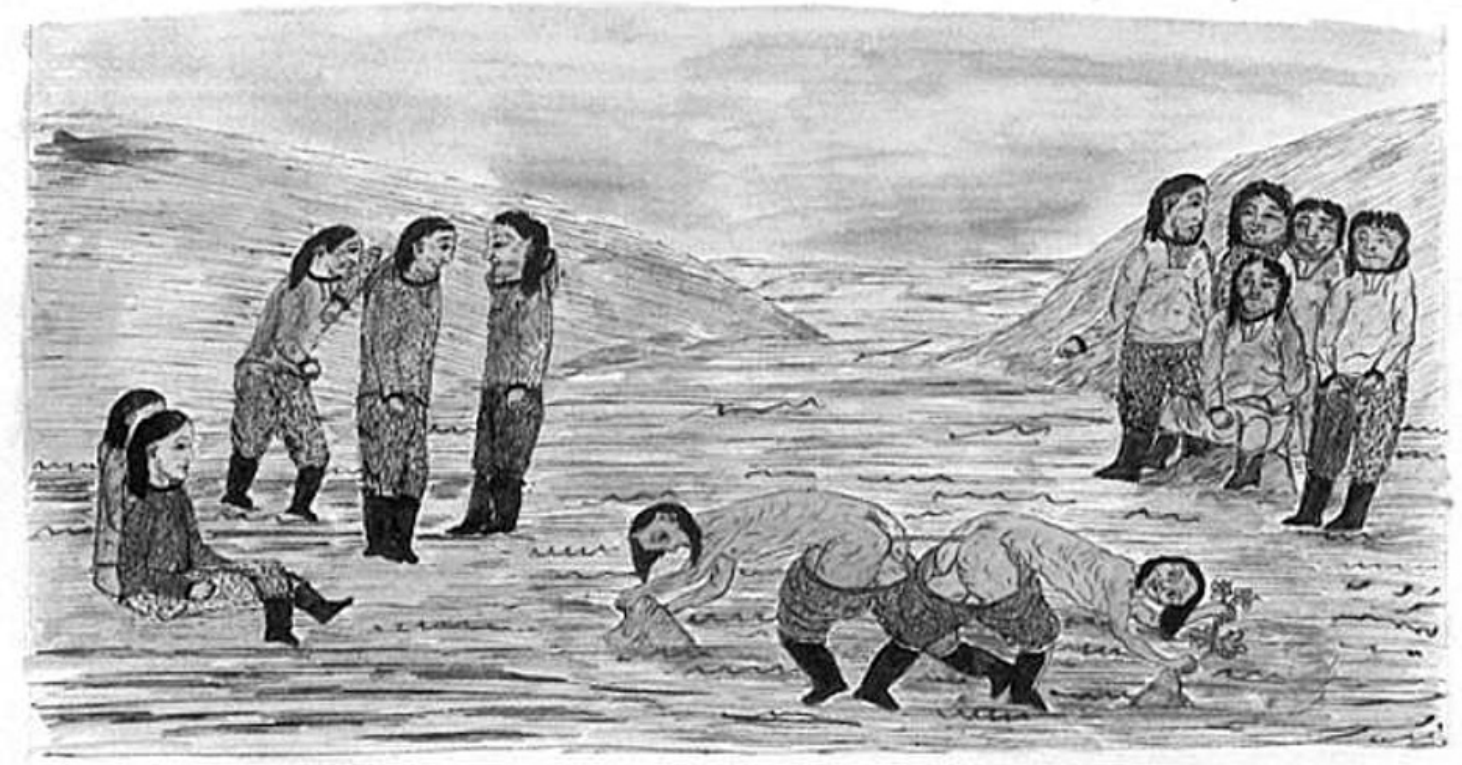

Inuit arse pull. Painting of Aron of Kangeq,19th century, in the Ethnographic Museum of Oslo. From: Thisted 1997, p.154, With friendly permission of Atuakkiorfik publisher, Nuuk.

All this pull and tug may be competitive, but it is not sport. It is a play with the grotesque sides of bodily existence. Besides the mouth and the 'arse', sexuality has always been a favorite of this presentation of the grotesque body ${ }^{16}$. Transvestite elements - men dressed like women and women behaving like men - were often a feature of popular festivity. In the Tartar festivity Sabantuy, a springtime holiday organised around korash wrestling, one can see a woman showing movements, which a man tries to imitate and all burst into laughter. By sexual parody, the tensions and unbalances between the genders in Tatar patriarchy are displayed and exposed to common laughter. ${ }^{17}$

\section{The fool}

The culture of laughter has furthermore brought forth a special role, a mask - the fool ${ }^{18}$. The jerk or tomfool was an important character of popular games and competitions. The Medieval Hausbuch from the fifteenth century shows a tournament of knights, which is accompanied by a horse race of

16 Bakhtin 1968.

17 Kuznezova, Milstein 1992.

18 Burke 1978; Mezger 1991; Cox 1969. 
peasants; fools underscore the grotesque movement of this race by among others pulling the horse's tail. ${ }^{19}$ On the copper engraving of Pieter Brueghel the elder, depicting the "Kermes of Hoboken" (1559) with its competitions, games and dances, one sees the fool in the foreground, holding children by his hand.

A special character of the foolish type was the Pritschenmeister, a droll or buffoon playing a central role in German urban shooting matches. ${ }^{20} \mathrm{He}$ had his name from the Pritsche, a wooden sword or slapstick, which is also used by Kasperle, the punch of German puppet folk theatre. The Pritschenmeister hoaxed and teased the bad scorer - even (or especially) if this was a highranking nobleman - presenting him a strange price of victory. It was a flag made of coarse sack cloth and fixed at a thorny branch - a parody of honour. The Pritschenmeister became in the sixteenth and seventeenth centuries a special class of poets linked to the urban shooting festivities. They held speeches including 'foolish' critical and humoristic undertones. They ranged somewhere between the popular tradition of disrespectful laughter - and a pompous Baroque type of order police. The fool in popular culture of laughter balanced between the 'real fool' who was a person with mental handicap, and the 'artificial fool' who played the role of hoaxing as a sort of artist. ${ }^{21}$ In Danish village festivities up to the twentieth century, a 'real' fool could be bestowed with the title of a leader of festivity ${ }^{22}$. His 'role' for one day balanced between being mobbed as a handicapped person and being socially integrated into the local community. ${ }^{23}$

\section{Carnival - festivity of the reversed world}

Games were the bodily part of popular festivity, and especially of those which turned the world upside down, the carnival. ${ }^{24}$ Here, the "real fool" would be king, and the king act as fool. In the ritualised anti-order of the farce and burlesque, the rules of the church, of aristocratic hierarchy, of the wealthy,

19 Schaufelberger 1972.

20 A Pritschenmeister hitting two persons on their arse, can be seen in a picture of a shooting match between three towns in St. Gallen, Switzerland, 1527. The serious modern historian comments and misunderstands this "strange service of order" as an odd "side issue": Schaufelberger 1972; Seytter 1904, 281-283; Deutscher Schützenbund 1961, 217; Graf von Pfeil 1975.

21 Gross 1990.

22 Personal communication of a Danish student in the 1980s, remembering this habit from her home village.

23 A particular version of the fool can be found in Trobriand cricket, visible in the classical anthropological film of Jerry W. Leach: Leach 1976. In this Melanesian game, the fool had the gestalt of 'the tourist' photographing the sportive event with a wooden camera.

24 Bakhtin 1968; Moser 1986; Dressen 1986. 
and of state authority were turned topsy-turvy. The principle of carnival was in high degree bodily. Normally, the body - like the populace - was 'down there'. Now for a day, the grotesque body was on the top. The carnivalism of the game is the context where the "penalty" - as in the case of Ljørslev was not a punishment like in modern sports, but an important ingredient of the game. Without 'mistake', there would be no drinking afterwards - thus without 'penalty' there would be no pleasure. Furthermore, it was not only the winners who would be rewarded, which was custom in urban shooting events, in aristocratic tournaments, and in modern sports. But the beer for the final feast was given by the victorious side - as in the case of the Cornish hurling. ${ }^{25}$ Turning the social world upside down, making a carnival, this was also a feature of bodily competition.

During the Middle Ages and up to early modernity, people from the upper classes joined this world of popular game and festivity, often as patrons, but also as players. In the seventeenth and eighteenth centuries, however, they retreated and cultivated their own courteous festivities, inventing quasiarchaic tournaments, geometrical carrousels, and horse ballets. From these events, the popular laughter was excluded. Laughter became a field of class struggle top-down. On the people's side, there was a gliding crossover from the spontaneous laughter of the folk to organised laughter, which laughed down certain persons - the charivari. Farmers organised themselves in secret societies, consisting mostly of young bachelors and celibates, who went to action, as soon as something went 'wrong' in society. In normal life, they would be responsible for, for instance, May festivities and rival with other territorial groups, among others by games and competitions. But they could also, demonically disguised and with blackened faces, appear at night to turn their 'weapon' - collective laughter - against some person who was accused to act against the rules of community. The people of this charivari organisation were often people from other places, who were called for support of the locals who thus remained undiscovered. The malefactor was forced to stand in the circle and be subject to ridicule, through speech and rhymes, mocking and hoaxing.

The charivari could become political. One of the latest cases was the riot around the so-called Habererbund, a secret society of peasants in the Bavarian Alps in the 19th century. It directed a spectacular charivari against a nobleman who installed industrial sawmills and by so doing was accused of make people jobless. The nightly organised laughter exploded in armed clash

25 The remuneration by the victorious side was a feature of many popular games around the world, among others of Al Kora, the hockey-like ballgame of Libyan Beduins. 
with police and military. It was not until WW I that the state succeeded in defeating this organisation of laughter. ${ }^{26}$

The Habererbund had some similarities with the way how farmers used La soule and similar football games. As this type of football spread out across the whole landscape, it suited well to damage the hedges and destroy the enclosures, which the landowners had forced upon the farmers, when taking possession of people's common land. The game of La soule, though a counteraction, was legitimated by old tradition and was 'just a joke', which the landowners had found difficult to resist. The game played over into politicaleconomic conflict. ${ }^{27}$

\section{The human being is not perfect}

There is no comprehensive title over the various elements that make up the configuration of popular laughter in games. But one pattern may have had a more embracing significance: the laughter at the failure. In popular games, the ridiculous failure of the other was balanced by the ironic laughter at one's own failure. Trying to hit the target means failing the target. Playing the loser means playing a failure. Tumbling and mock fight create ironic situations of the unwanted outcome. The grotesque body is a display of what is un-perfect in human shape. The fool and the carnival are images of what is going 'wrong' in life. All this gives birth to laughter, which, thus, is linked to a deep recognition of human failure - and it is excluded by a culture of perfection.

In other words, the human being is not perfect - this was the narrative of the popular games. This non-perfection was expressed by carnivalistic laughter. In contrast, modern sport was built up around the expectation, that the human being should be perfect. The human being should be healthy, strong, fit, and well-trained. This was a new concept of human life - and new understanding of health.

\section{Modern sports: Laughter goes underground}

The dialectics between failure and perfection deliver, thus, a background for understanding the modern repression of laughter. The process of earlymodern state formation was accompanied by many forms of prohibition and prosecution, which were directed against popular laughter and the related 
forms of festivity and games. These have been described elsewhere in detail ${ }^{28}$. For the body cultural topic, the prosecution of football and La soule through centuries is especially illustrative ${ }^{29}$. 'Disorder' and 'violence' were the main arguments of this repression, both causing harm and damage. Against these 'unhealthy' aspects, power should guarantee healthy order.

The direct repression by prohibitive edicts had, however, a very limited punch. More effective were the attempts to create alternative and 'well-ordered' forms of body culture. Authorities tried to transform local kermes festivities into military parades and muster. ${ }^{30}$ But it was especially modern sport, which became an efficient instrument of disciplining popular culture, able to replace the old games. Sport combined enjoyment and entertainment with streamlining after the patterns of industrial strain - avoiding the carnival-like elements of popular games.

In modern sport, the fool and the carnivalesque Pritschenmeister of the early modern riflemen's meeting disappeared. When competition and play became a way of production ${ }^{31}$ - the production of results and records laughter became marginal or even dysfunctional. Neither the umpire or referee of sports nor the Olympic functionary handing over the medals is a fool or could be replaced by a fool. Also the new-constructed discipline of 'sport history' describing the rational and progressive development of the principle of performance had to forget the laughter - and the history of its disappearance.

On the level of intellectual superstructure, one has stated for the case of Germany that Enlightenment drove laughter out of the understanding of human life. ${ }^{32}$ From Immanuel Kant to Jürgen Habermas, there is no link between laughter and the quest of truth in philosophy. Fundamental to this shift was the change of bodily-practical patterns. From now on, there was to be no push and shove on the agenda of sport, no pull, no playing the loser, no mock fight - and no laughter on the churchyard. And very few hitting-thepoint games and exercises of balance were left. Races, throwing, and water activities were rationalized towards the production of results and records citius, altius, fortius.

28 Thomas 1977; Burke 1978; Dressen 1986.

29 Typical was a conflict arising between authorities and people of the Breton town Commana in 1777. People used the annual Catholic procession for competitions among the bearers of heavy flags and crosses. The priests and authorities regarded this game of laughter as indecent and banned it, which caused some popular revolt and unrest. Eichberg 1998, 202-203.

30 Schaufelberger 1972.

31 Eichberg 2003.

32 Communication from Lothar Mikos, International colloquium «Le rire européen», Perpignan 2007. 
By this change, sport and circus were separated. Or in other words, while sport occupied the terrain of seriousness, circus shaped its own realm. Both phenomena were specifically modern. Both displayed in some way bodily excellence and 'acrobatic' skill. But the one of them - the circus - kept the clown as a central figure. This is why during at least one century, sport - and especially the pedagogy of Physical Education - were eager to distance from circus as being 'non-serious' and a joke.

Gymnastics which during the nineteenth century tried to develop as an alternative to sport, competed in the degree of seriousness. The participants had to behave 'correctly' after defined rules of medical-scientific, educational or aesthetic character. None of these rules made room for laughter. Though there may have been some single gymnastic instructors who developed a laughter-provoking or moderately clown-like style. In mass gymnastics as in the East European Spartakiads, laughter was regarded as counterproductive or even subversive. ${ }^{33}$ These modern gymnastics expressed the modern concept of health as deeply serious, nothing to laugh at. To this practice corresponded the different theories of sport achievement and of sport action like Anglo-American functionalism as well as the 'oppositional' German Handlungstheorie of the 1980s. They made laughter systematically and theoretically disappear. ${ }^{34}$ And yet, sport is practiced by human beings, and human beings laugh. Laughter in sports went underground. A phenomenology of laughter in modern sports looks different to that in popular games.

\section{Laughter of superiority}

In sport, one may hear the triumphant laughter and screams of euphoria. Since the 1990s, this has developed towards more and more formalized jubilation rituals, where the winners of soccer dance laughing in front of the public, and the winner of athletics runs a victory lap with the national flag around the stadium. If this turns with some deriding and mocking undertones against the loser, it would not be fair style, not 'good sport'. Laughter is here about athletic success, not about failure. The one-sided laughter of triumph following one's own success fits into the culture of rivalling for the top-position in the modern pyramid of sport. ${ }^{35}$

33 Roubal 2007, 88 et 97.

34 Eichberg 1985.

35 The pyramid as iconic model of sports was - again - launched by the report to the European Community: Arnaut 2006. 
The top-down laughter, from the position of the superior, may correspond to what since Henri Bergson has been theorised about by modern philosophers of laughter. ${ }^{36}$ Here, laughter has the function of derision, of laughing down the scapegoat. Making fun of the other, this was also the background for some feminist theorists who felt their gender insulted by male laughter and in reaction considered a sort of laughter strike. ${ }^{37}$ The understanding of laughter as a top-down scorn was also the root of the modern misunderstanding that playing the loser in popular games was a way of determining the scapegoat or a process of punishment. ${ }^{38}$

\section{Failure as drama}

Toppling on the race track, falling down from the gymnastic bar, tumbling on the soccer ground - all this happens in the world of sports, but it is regarded as accident, not as a welcome situation of laughter. For the spectator, it may take one's breath away when seeing the top-runner falling - this is a drama, and the unlucky tumbler may burst into tears. Or the failure will result in screams of rage and an explosion of fury, not in laughter. Sport - in contrast to popular game - is the arrangement of movement along a scale of results. At the produced numbers - centimetres, grams, seconds, and points - there is nothing to laugh. Seen in this comparison, the laughter of popular games had a reflective character while the process of production, achievement, and perfection in modern sport lacks this reflexive element. (In sport one finds rather a technological reflexivity: How do I achieve in a more efficient way?) In the light of this observation, the fashionable theses about the "reflexive modernity", launched by sociologists like Anthony Giddens and Ulrich Beck, sound superficial.

\section{Smile of the want-to-be winner}

Generally, there seems to be more smiling than laughter in sport. For the public, the victorious athlete smiles into the camera. In this situation, the athlete does neither laugh at others nor at something nor at oneself, but the athlete presents his or her own image by smiling: 'Look at me!'

36 Bischof 1986.

37 Kotthoff 1996.

38 Eichberg 1978.

Gesnerus 70 (2013) 
Smiling expresses happiness, which is important for creating social atmosphere and facilitating communication. However, smiling fitted also very well to the cult of happiness under regimes like Soviet Stalinism. While laughter was regarded as a dangerous subversion against the Stalinist system, the iconology of smiling was strongly promoted by the means of painting, sculpture, and movie. ${ }^{39}$ There was a deep contradiction between the smile of 'socialist happiness' on one side and the subversion of laughter on the other. That is why the smiling sports athlete played an important role in Stalinist 'socialist realism'. There is no failure and there cannot be any failure in the perfection of 'scientific communism', therefore laughter has to be mistrusted. This may throw light on some deeper connections between the striving of perfection in sports and the cultivation of smiling. And on the links between the repression of failure and the disappearance of laughter.

\section{Fitness smile}

In modern body culture, there developed a rivalling model side by side with sport: gymnastics. Also in fitness gymnastics, the fitness athlete is trained to keep-smiling. Fitness smile is part of the health-sportive habitus and was upgraded by the recent wave of health-orientation: to smile under hard fitness work ${ }^{40}$. If there is pain in the body, just smile - this is what the hygiene of fitness movement is teaching ${ }^{41}$. Aesthetical sports like synchronised swimming have taken this over.

The exercises of gymnastics and fitness aim at perfection. That is why laughter has no legitimate place here. In the popular practice of gymnastics, however, the failure may give rise to laughter, and in this way, the Danish so-called folkelig gymnastics show some carnivalistic underground under the surface of modern disciplining exercises. Laughter and smile are different in bodily rhythm. Where the laughter of games is a spontaneous eruption, the smiling of fitness expresses self-control and normalization ${ }^{42}$. There is no 'burst of smiling'. The difference between laughter and smiling finds its expression in the superstructure of pictures and discourses. Smile characterizes the iconology of fitness industry - smile on advertisements, smile on the front-page of fitness magazines, smiling personal in the welcome section of the health club. The smile is an interpersonal mark of the selling relation.

39 Lauchlan 2007.

40 Rittner 1986.

41 Engelsrud 2007, 94-95.

42 Holten-Andersen 2007, 199. 
Dale Carnegie, the guru of self-improvement, salesmanship, and corporate training, underscored as early as in 1936 in his main work How to Win Friends and Influence People:

An insincere grin? No. That doesn't fool anybody. We know it is mechanical and we resent it. I am talking about a real smile, a heart-warming smile, a smile that comes from within, the kind of smile that will bring a good price in the market place. ${ }^{43}$

Laughter expresses humour in quite another way. An American woman remembered her first entry into a fitness club, together with a friend, in the 1970s, when this milieu was still a men's domain:

We were the only women, of course. And it was great (...) I was really strong. No one ever thought a woman would ever want to lift weights. It was a feminist thing at the beginning my friend and I were the only women. We were laughing, and the guys thought we were so weird, but you know, we got the goods! (Laughs). So you got to conform and not to conform, which is always the best. ${ }^{44}$

Here, laughter had subversive qualities. It changed the given situation and relations. And yet, the difference between subversive laughter and selling smile may not be universalized. In other cultural context, both may have quite different connotations. Some lands in the world are for instance called "land of smiles" - Thailand, China, and Japan, also Burma and Indonesia. Though this may nowadays as a slogan enter into touristic sale promotion, the cultural-psychological background is original. Its iconology can be found in the smile of Buddha. A deeper bodily practice connected to this is the "inner smile" of the Taoist Chinese tradition. When the master "smiles to his abdomen", the master works on his own chi energy. Facial smile is linked to the "sleeping" of the brain and "smiling" of the "second brain" in the lower $\tan$ tien or hara ${ }^{45}$ Smile and smile is not just the same.

\section{Fan laughter}

Beneath the surface of mainstream sport and gymnastics, however, there is some more polyphonic sound in the larger world of sports. There one finds dissidence and an underground of laughter. Carnival has for instance invaded the world of the fans. Fan laughter is highly differentiated. The communityembracing laughter of the soft supporter, who appeared during the 1980s and in Danish is called roligan, contrasts the aggressive laughter of the violent supporter, the hooligan. Recent supporter fractions as "ultras" and "casuals"

43 Maguire 2008, 35.

44 Maguire 2008, 67.

45 Chia 2005, 37-41, 46-47. 
further differentiate this picture ${ }^{46}$. Together, they manifest the underground presence of festivity and laughter.

Again, however, disciplining strategies are on their way. Cheer-leading produces and trains a formalised, militarised form of smiling culture. ${ }^{47}$ Getting the laughter of the supporter home to modern happiness... Another colonization process showed around the phenomenon of streaking. ${ }^{48}$ Since the early 1970s, one could now and then see naked persons running from the supporter tribune down into the sports field, attracting the forces of order - and the cameras of media. Developing with a background in the counter-culture on university campuses, streaking could be placed somewhere between demonstration, taboo-breaking provocation, personal pleasure and personal craze. What had been an action of shocking the public or make them laugh, was, however, during the 1990s discovered by entertainment industry and related business interests as a field of possible exploitation. Enterprises began to hire streakers to advertise on their naked bodies, and a strange melange of soft porno and commercialisation showed up.

\section{New games - new circus}

From the underground of modern movement culture, the New Games of the 1970/80s brought a new form of carnivalism into the world of sports (or antisports). This had a background in Californian hippie culture. In New Games, it was the process, not the result that counted. By this impulse, the activities of the acrobat and the clown received a new attraction and invaded school sport and Physical Education. This was a fundamental break with 200 years of educational attempts to keep distance from the 'unserious circus'. Maybe, the movement of New Games, which in some Nordic countries was at the roots of the recent rediscovery of traditional games, was more significant than it seemed to be. On its surface, it had only seasonal duration, appearing with hippie culture and vanishing again in a period of cultural restoration. But it opened a door towards new culture of laughter inside modern movement practice.

46 Joern 2007.

47 Macdonald 2004.

48 Carrington; McDonald 2006. 


\section{Dark laughter?}

What deserves a closer analysis is the role of laughter in other types of underground activities, in the world of subversive and 'dark games'. They extend from the softer versions like the recent street-movements park our and urban tricking over façade climbing and bungee jump to dangerous games like metro-surfing. The game-researcher Brian Sutton-Smith has earlier warned against the idealisation of play and game, pointing to games of risk and danger, which are typically undertaken under the influence of alcohol. ${ }^{49}$ Many of these non-sportive activities are characterised by laughter. So there is no reason to idealise laughter as well. Or to ask in another way, are there certain ways of underground laughter corresponding to what in history has been called the 'diabolic laughter' or 'insane laughter'?

\section{And the laughter of traditional games?}

Under the aspect of laughter, the survival and renaissance of popular games as 'traditional games' can be seen in a critical perspective. In certain rural, often marginal environments, old games may, indeed, have kept their connection with the culture of popular carnivalism. When reappearing, however, when we talk about a 'renaissance' and the games are transformed into something 'traditional', they enter into a new, modern world. Under these conditions, the restoration of old popular culture is not a realistic option. What is happening in some milieus is a sportization of old games. Turned into competitive sports, they establish a new connection with the pattern of achievement and result - and they lose their connection with laughter.

Another transformation may happen under the heading of folklorization. Games are put into museum frames or set on a scene, being shown off as representation of something 'traditional', 'regional' or 'national'. Also this is a serious project, focusing on 'correct' performance of 'original' forms, and there is nothing to laugh at.

A third approach is setting the games into an educational context. Pedagogization is a realistic option, especially in welfare societies with their strong educational focus. This is what one has experienced in Denmark when reviving the 'old village games' during the 1980s and 1990s. And yet, also this approach may make laughter disappear and, thus, transform the games into an instrument of learning, schooling, and discipline. If trying to avoid the

49 Sutton-Smith 1983.

Gesnerus 70 (2013) 
strategies of sportization, folklorization, and pedagogization, what to do? The Gerlev Center for Play and Movement Culture (formerly Idratshistorisk Varksted) in Denmark has since the 1990s built up a place of experimental play culture, trying to meet these challenges. ${ }^{50}$ When approaching this playground from far, one hears the sounds of rolling bowls - and of laughter. Laughter is not displayed or arranged here, but it tells a side-story about human bodily practice - which may be a main story of social health.

\section{Laughter as a convulsion of the social body - and social health}

On the level of social theory, the contradictory history of laughter in games and modern sport and after can stimulate further questions about the social and psychological connections between the processes of sportization, modernization, and the suppression of laughter. This throws, more generally, light on the - subversive? - role of laughter in the development of modern Western achievement culture in relation to production and power, and all this on the level of bodily practice. What rises at the horizon is the anthropology of laughter. ${ }^{51}$ Anthropology touches three levels - the body, the soul, and social relations.

Laughter has a bodily basis. ${ }^{52}$ Laughter is more than an expression of a cognitive point - like the joke - and more than an expression of emotion, as the related terms 'humour' and 'merriment' may demote. Laughter is also related to the body-nonsense of the slapstick - from Charlie Chaplin, Buster Keaton, and Laurel and Hardy to Mister Bean. Laughter is physically convulsive. One can talk about a "physiology of laughter" ${ }^{53}$ But attention, the science-conform term 'physiology' can be misleading, as the bodily laughter cannot - like biological physiology - be decoupled from cultural practice. And yet, as a bodily process of convulsion, laughter is existential and universal - like pain, schadenfreude, hubris ... ${ }^{54}$

At the same time, laughter is an explosion of psychical energy and creates social-psychic atmosphere. ${ }^{55}$ How this energy - with its physical and psychic dimensions - can be understood in the framework of cultural studies, remains a so far open question. ${ }^{56}$

50 Eichberg/Nørgaard 2005.

51 Plessner 1982.

52 Hall, Allin 1897.

53 Hager 1986, 305-6.

54 Morris 1991, McNamee 2002, McNamee 2003, McNamee 2006.

55 Hall, Allin 1897.

56 Eichberg 2008. 
And last but not least, the bodily and energetic process of laughter is linked to social relations. The phenomenon of tickling is illustrative: We cannot tickle ourselves - we can only be tickled by other people. This shows the limits of the physiological approach - and it shows that social relation is bodily in a very special way: it is inter-bodily.

These three levels of laughter enter into a surprising consonance with those three dimensions of health, which have step by step been discovered by modern health policies. World Health Organization defined in 1948: "health is a state of complete physical, mental, and social well-being and not merely the absence of disease or infirmity." This was confirmed in the WHO Ottawa Charter for Health Promotion, 1986, understanding the aim of health promotion as "to reach a state of complete physical, mental, and social wellbeing" and adding: "Health promotion is the process of enabling people to increase control over, and to improve, their health." While health systems through at least two centuries have invested heavily into experts, institutions, and practices focusing on the physical side, the mental side (emotional, subjective, and relational health) as well as the social side (co-operational and mobilized health) have been strikingly underinvested. Play and game are a part of this world of healthy practice, and laughter is an expression of this 'other health' ${ }^{57}$ The sound of laughter tells about imperfect people struggling for control over their life.

"Laughter is healthy", says an old popular wisdom. As shown by popular games, the health of laughter recognizes the imperfect nature of the human being. This is another understanding of health than the strategy of perfection and normalization, which characterized medicine, sports and gymnastics in classical industrial culture. Now the modern expert's wisdom was that "sport is healthy". This saying was never quite accepted by critical observers, and the poet Bertolt Brecht remarked trenchantly that great sport began just there where it was no longer healthy. ${ }^{58}$ This objection is, however, not only true for the great sport, but for broad mass activities, too. At the machines of sportive fitness culture, young people and even children train themselves towards the body of Tarzan (with doping) and Barbie doll (with anorexia). Healthy? What is 'healthy', changes through history, and there is not just one health.

57 A strange phenomenon going through current culture is the movement (or enterprise) of therapeutic laughter. In 1995, a physician from Mumbai (India), Madan Kataria, started the first club of Laughter Yoga (Hasya Yoga). Since that, over 5000 Laughter Clubs have been created in 40 countries. Some forerunners can be seen in sectarian initiatives in America, launched by Scientology of L. Ron Hubbard and Dynamic Meditation of Bhagwan Shree Rajneesh, and in the work of Norman Cousins.

58 Brecht 1928, 582-584. 
In other words, laughter marks social health inside popular culture but health can be different things. The sportive disappearance and (postsportive?) reappearance of laughter tells about the contradictory nature of modern body culture. Laughter is not harmless - just like play and game, and like medicine. Laughter is human - and it can be 'diabolic'... And the academic discourse about laughter is not harmless, either. What happens when the cold hand of academia (and the scientific understanding of health) takes grip of the human convulsion of laughter?

\section{Bibliography}

Arnaut, José Louis, Independent European Sport Review 2006, http://www.independentfootballreview.com

Bakhtin, Mikhail, Rabelais and his World (Cambridge 1968)

Bischof, Rita, «Lachen und Sein. Einige Lachtheorien im Lichte von Georges Bataille», in: Dietmar Kamper/Christoph Wulff (eds.), Lachen - Gelächter - Lächeln (Frankfurt 1986) 52-67

Brecht, Bertolt, «Die Krise des Sports» (1928), in: Bertolt Brecht, Gesammelte Werke, 8 (Frankfurt 1967) 582-584

Burke, Peter, Popular Culture in Early Modern Europe (London 1978)

Carew, Richard, Survey of Cornwall (London 1811)

Carrington, Ben/IanMcDonald, "The ontological impossibility of the Black streaker: Towards a sociology of streaking", Unpublished manuscript (2006)

Carter, John Marshall/Arnd Krüger (eds.), Ritual and Record. Sports Records and Quantification in Pre-Modern Societies (New York 1990)

Chia, Mantak, Energy Balance Through the Tao. Exercices for Cultivating Yin Energy (Rochester, Vt 2005)

Cox, Harvey, The Feast of Fools. A Theological Essay on Festivity and Fantasy (Cambridge 1969)

Depping, Guillaume, Die Körperkraft und Geschicklichkeit des Menschen. Historische Darstellung der Leibesübungen bei den alten und neueren Völkern (Minden 1881)

Deutscher Schützenbund, Wir Schützen. 800 Jahre deutsche Schützen. Das offizielle Dokumentarwerk (Stuttgart 1961)

Dressen, Wolfgang, «Possen und Zoten. Ausflüge unter die Gürtellinie», in: Dietmar Kamper/ Christoph Wulff ( eds.), Lachen - Gelächter - Lächeln (Frankfurt 1986) 147-169

Eichberg, Henning, Leistung, Spannung Geschwindigkeit (Stuttgart 1978)

Eichberg, Henning, «Handlung, Spielraum, Spiel-Raum. Sozialökologische Bedenken und etwas über das Lachen», in: Günter Hagedorn/Herbert Karl/Klaus Bös (eds.), Handeln im Sport (Clausthal-Zellerfeld 1985) 77-98

Eichberg, Henning, "From modernization to "postmodernity", in: Jean-Jacques Barreau/Guy Jaouen (éds), Eclipse et renaissance des jeux populaires (Rennes 1998) 99-129

Eichberg, Henning, «Die Produktion des 〈Unproduktiven»», in: Manfred Lämmer/Barbara Ränsch-Trill (eds.), Der künstliche Mensch - eine sportwissenschaftliche Perspektive? (Sankt Augustin 2003) 112-140

Eichberg, Henning, "Three dimensions of playing the game: About mouth pull, tug-of-war and sportization”, in: Verner Møller/John Nauright (eds.), The Essence of Sport (Odense 2003) $51-80$

Eichberg, Henning, "Racing in the labyrinth? About some inner contradictions of running", Athletics, Society \& Identity 5 (2005) 169-192

Eichberg, Henning/Kit Nørgaard, "Education through play and game - Danish experiences", International Journal of Eastern Sports \& Physical Education 3 (2005) 166-197

Eichberg, Henning, "The energy of festivity. Atmosphere, intonation and self-orchestration in Danish popular sports", in: Anthony Bateman/John Bale (eds.), Sporting Sounds. Relationships between Sport and Music (New York 2008a) 99-112 
Eichberg, Henning, «Nauru urheilussa ja kansanleikeissä: Kohti nauramisen fenomenologiaa», Suomen urheiluhistoriallisen seuran vuosikirja (2008b) 157-179

Eichberg, Henning, "Laughing in sports and popular games: Towards a phenomenology of laughter", in: Anne Chamayou/Alastair B. Duncan (eds.), Le rire européen (Perpignan 2010a) 305-326

Eichberg, Henning, "Sport and Laughter: Phenomenology of the Imperfect Human Being", in: Henning Eichberg (ed.), Bodily Democracy. Towards a Philosophy of Sport for All (New York 2010b) 161-179

Eichberg, Henning, «La risa en los juegos y deportes populares: Hacia una fenomenología de la gente risueña», in: Guy Jaouen/Pere Lavega/Carlos de la Villa (éds), Juegos Tradicionales y Salud Social. Jeux traditionnels et santé social. Traditional games and social health (Aranda de Duero 2010c) 145-169

Eichberg, Henning, «Le rire dans les jeux populaires: Une autre voie pour la santé, en jouant», in: Guy Jaouen/Pere Lavega/Carlos de la Villa (éds), Juegos Tradicionales y Salud Social. Jeux traditionnels et santé social. Traditional games and social health (Aranda de Duero 2010d) 132-145

Engelsrud, Gunn, Hvad er krop? (Copenhagen 2007)

Graf von Pfeil, Sigurd, Schützenwesen und Schützenfeste in Niedersachsen (Göttingen 1975)

Gross, Angelika, <La folie». Wahnsinn und Narrheit im spätmittelalterlichen Text und Bild (Heidelberg 1990)

Hager, Frithjof, «Können Tiere lachen?» in: Dietmar Kamper/Christoph Wulff (eds.), Lachen Gelächter - Lächeln (Frankfurt 1986) 301-31

Hall, Stanley/Arthur Allin, "The psychology of tickling, laughing, and the comic", American Journal of Psychology 9 (1897) 1-41

Henningsen, Henning, Dystløb i danske søkøbsteder og $i$ udlandet (Copenhagen 1949)

Holten-Andersen, John, Vanvid og virkelighed. En фkologisk omtankning (Højbjerg 2007)

Hornby, Hugh, Uppies and Downies. The Extraordinary Football Games of Britain (London 2008)

Joern, Lise, Homo fanaticus - passionerede fodboldsupportere (Gerlev 2007)

Keewatin Inuit Associations, Inuit Games (Rankin Inlet 1989)

Korsgaard, Ove, Krop og kultur (Odense 1986)

Kotthoff, Helga (Hrsg), Das Gelächter der Geschlechter. Humor und Macht in Gesprächen von Frauen und Männern (Konstanz 1996)

Kuznezova, Zinaida/Oleg Milstein, "Traditions of the Tatar Cultural Minority”, in: Leena Laine (ed.), Sport and Cultural Minorities (Helsinki 1992) 282-284

Lauchlan, Iain, "Laughter in the dark: the Soviet Union under Stalin", in: Anne Chamayou/ Alastair Duncan (eds.), Le rire européen (Perpignan) 257-274.

Leach, Jerry W., Trobriand Cricket - an Ingenious Response to Colonialism (Berkeley 1976)

Macdonald, Charlotte, "Putting bodies on the line. Marching spaces in Cold War culture", in: Patricia Vertinsky/John Bale (eds.), Sites of Sport. Space, Place and Experience (New York 2004) 85-100

Maguire, Jennifer S., Fit for Consumption. Sociology and the Business of Fitness (New York 2008)

Mantak, Chia, Energy Balance through the Tao. Exercises for cultivating Yin Energy (Rochester 2005)

McNamee, Mike, "Hubris, humility, and humilation: Vice and virtue in sporting communities", Journal of the Philosophy of Sport 29 (2002) 38-53

McNamee, Mike, "Schadenfreude in sport: Envy, justice and self-esteem", Journal of the Philosophy of Sport 30 (2003) 1-16

McNamee, Mike, "Suffering in and for sport:Some philosophical remarks on a painful émotion", in: Sigmund Loland/Berit Skirstad/Ivan Waddington (eds.), Pain and Injury in Sport. Social and Ethical Analysis (New York 2006) 229-245

Mezger, Werner, Narrenidee und Fastnachtsbrauch. Studien zum Fortleben des Mittelalters in der europäischen Festkultur (Konstanz 1991)

Moëlo, Serge/Jean-Pierre Le Bihan, Kergohann hag ar vellad./Kergohann et la soule (Loudéac 1986)

Møller, Jørn, "Sports and old village games in Denmark", Canadian Journal of History of Sport 15 (1984) 19-29 
Møller, Jørn, Gamle idratslege i Danmark [Old movement games in Denmark] (Gerlev 1997)

Moser, Dietz-Rüdiger, Fastnacht - Fasching - Karneval. Das Fest der «Verkehrten Welt» (Grazl Vienna/Köln 1986)

Morris, David B., The Culture of Pain (Berkeley 1991)

Nitschke, August/Justin Stagl/Justin Dieter/R. Bauer (eds.), Überraschendes Lachen, gefordertes Weinen. Gefühle und Prozesse, Kulturen und Epochen im Vergleich (Vienna/Köln/Weimar 2009)

Plessner, Helmuth, Lachen und Weinen. Eine Untersuchung der Grenzen menschlichen Verhaltens (Bern 1941), in: Helmuth Plessner, Gesammelte Schriften, 7 (Frankfurt 1982) 201-387

Renson, Roland, "Folk football: Sport and-or-as ritual?", in: Proceedings of the 9th International HISPA Congress. Sport and Religion (Lisbon 1981) 275-284

Rittner, Volker «Das Lächeln als mimischer Stossdämpfer», in: Kamper, Dietmar/Christoph Wulff, (Hrsg.), Lachen - Gelächter - Lächeln (Frankfurt 1986) 322-337

Roubal, Petr, Embodying Communism: Politics of Mass Gymnastics in Post-War Eastern Europe (Budapest 2007)

Schaufelberger, Walter, Der Wettkampf in der Alten Eidgenossenschaft. Zur Kulturgeschichte des Sports vom 13. bis ins 18. Jahrhundert (Bern 1972)

Seytter, Wilhelm, Unser Stuttgart (Stuttgart 1904)

Sutton-Smith, Brian, «Idealisierung des Spiels», in: Ommo Grupe et al. (eds.), Spiel - Spiele Spielen (Schorndorf 1983) 60-75

Thisted, Kirsten, Jens Kreutzmann. Fortcellinger og akvareller (Nuuk 1997)

Thomas, Keith, "The place of laughter in Tudor and Stuart England", Times Literary Supplement 3-906 (1977) 77-81

Tomschik, Erich et al., Der Markgröninger Schäferlauf (Markgröningen 1971)

Wolfram, Richard, Schwerttanz und Männerbund (Kassel 1936) 